\title{
NIKOLAOS PAPANIKOLAOU
}

\section{THE ROAD TOWARDS THE ESTABLISHMENT OF THE EUROPEAN BANKING UNION}

\author{
Avó
}

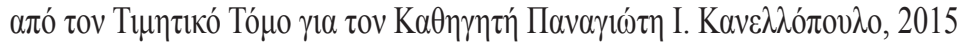

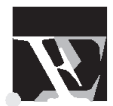

EK $\triangle \mathrm{O} \Sigma \mathrm{EI} \Sigma \Sigma \mathrm{AKKOY} \Lambda \mathrm{A}$

A OHNA - OE $\Sigma \Sigma A \wedge O N I K H$ 



\title{
The road towards the establishment of the European Banking Union
}

\author{
Nikolaos I. Papanikolaou \\ Assistant Professor of Banking and Finance, University of Sussex \\ Visiting Assistant Professor, University of Luxembourg
}

\section{Introduction}

The turmoil in the international financial markets, whose origins can be traced in the rising delinquencies in the U.S. subprime mortgage market in 2006 and the succeeding collapse in housing prices in August 2007, had a considerably negative impact on the functioning of the European financial systems and the smooth operation of the European economies as a whole. Indeed, in the Euro-area, what started as a financial crisis escalated to a twin crisis after being doubled by the eruption of a massive sovereign debt crisis in 2010.

A large number of banks in Europe either failed or received significant financial aid during the late 2000 s crisis by national authorities thus inflicting substantial losses on the entire system. In an effort to help financial institutions that were teetering on the edge of failure to stay afloat and to increase the level of liquidity in the economy the European Central Bank (ECB) also took severe action implementing several non-standard, urgent policy measures. Apparently the key purpose of the series of bank rescues was for national authorities to avert the sudden collapse of the troubled institutions. But even more importantly, national bank bailout policies coupled with ECB strategies were aiming at maintaining the stability of the system and containing the systemic risk in financial markets.

From an economic viewpoint, the recapitalisation of problem banking institutions doubled with the cost of bank failures and that of large stimulus programmes which sovereigns launched to revive demand led to the explosion of public debt in 2010 in the Euro-periphery economies but also in their core counterparts. This sort of fiscal problems were -to a great extent- responsible for the upsurge in the sovereign risk that was observed, which put a further upward pressure on countries' borrowing costs. Within that context, several borrowed countries faced considerable difficulties in repaying their loans or obtaining new loans from the markets as they were locked out from them. By contrast, the relevant academic literature shows that a well-functioning and robust banking sector strengthens the stability of the entire financial system to a great extent and is a crucial determinant of economic growth 
(see, e.g., Koetter and Wedow, 2010) ${ }^{1}$.

The lack of an established set of bank supervision and resolution strategies at the Euro-area level, the vicious circle between banks and the European nation-states which was revealed after the onset of the crisis and gave rise to the dramatic upsurge of sovereign risk, the threats for the sustainability of the common currency itself, and the deterioration of the market conditions were the key factors which led to the acceleration of the steps towards the creation of a banking union in Europe. The principal aim of the European Banking Union (EBU) is to shape the necessary legal and institutional framework and provide the authorities with powers and tools to deal with ailing banks in order to prevent the devastating effects that a future shock may have on the financial system, the real economy, and the society like it was the case in the late 2000 s crisis.

The rest of this study is organised as follows. Section 2 presents the formal reactions of the sovereigns and the ECB to the twin crisis prior to the establishment of the EBU. Section 3 discusses the key problems and the inherent weaknesses which led European policy-makers to take the decision to establish a common banking union for the Euro-area member states. Section 4 presents the structure of the EBU and the different aspects of its operation, and Section 5 offers some concluding remarks.

\section{Dealing with the twin crisis in Europe before the establishment of the EBU}

\subsection{The response of the sovereigns to the twin crisis}

When the financial crisis crossed the Atlantic, a number of banks in the Eurozone started facing considerable liquidity problems which were mainly due to the boomand-bust developments in the real estate markets, the collapse of the market prices of a number of modern structured financial products that banks were highly exposed to, the virtual closure of the interbank market which made banks unable to lend to each other, and the subsequent inability of firms, households, and sovereigns to repay their loans to the banks. In the absence of a supranational authority to deal with the problem banks, national governments had to be the ones to financially support their banks based on internally designed bailout policies.

The first sovereign Eurozone state to experience the need to bailout its banks was Ireland. Although the decision of the Irish Government in September 2008 to legislate for a blanket guarantee of the liabilities of the biggest and most important

1. The smooth operation of financial markets, which is the second pillar of the financial system, also plays a fundamental role in maintaining the stability of the system. In fact, the role of financial markets is complementary to that of financial intermediaries. 
commercial banks was taken on the basis of advice that banking institutions faced liquidity and not solvency difficulties, it soon became generally accepted that the equity capital of several banks should be boosted due to the steady fall in property prices, the deepening recession, and a growing realisation that the banks' exposure to residential mortgage lending had created a large and hard-to-quantify risk of loan-losses. Therefore, in December 2008, and in the aftermath of the Lehman Brothers collapse, the government announced its decision to inject capital into the largest Irish banks with the purpose to keep them afloat and stabilise its financial sector ${ }^{2}$.

Even though Ireland went into the crisis with a relatively low level of public debt, budgetary overruns emerged and a sharp deterioration in public finances occurred as a result of the sudden additional burden of filling the growing capital hole in its banking sector. By the end of 2010, the yield spreads for Ireland and the other periphery economies had deteriorated to the point where debt sustainability could no longer be assured. As a consequence, the Irish Government could do nothing else but to cease borrowing from capital markets at unaffordably high interest rates and sought the assistance of its counterparts in the EU in order to continue the process of strengthening the capital base of its banks and stabilise its economy. The then newly-established tripartite committee led by the European Commission (EC), the ECB and the International Monetary Fund (IMF), later nicknamed as the Troika, took the decision to provide sufficient funding to Ireland to recapitalise its banks and also cover the additional costs of deleveraging the Irish banks so that their reliance on Irish government funding to be reduced. To do this, the Troika resorted to the European Financial Stability Facility fund (EFSF), which had been set up earlier that year as a temporary crisis resolution mechanism with the objective of preserving stability in Europe by providing financial aid to the troubled Eurozone states $^{3}$. The result was a very delicate balance established in 2011 between ensuring

2. On September 15, 2008, Lehman Brothers filed for bankruptcy. With $\$ 639$ billion in assets and $\$ 619$ billion in debt, Lehman's bankruptcy filing was the largest in history. Lehman was the fourth-largest U.S. investment bank with 25,000 employees worldwide. Its failure was a seminal event that greatly intensified the late 2000 s crisis and contributed to the erosion of $\$ 10$ trillion in market capitalisation from global equity markets in October 2008, the biggest monthly decline on record at the time.

3. The EFSF was financed by the Eurozone member states with a total amount of $€ 440$ billion. It could issue bonds or other debt instruments on the market with the support of the German finance agency to raise the funds needed to provide loans to the Eurozone sovereigns that were facing financial problems. Emissions of bonds would be backed by guarantees given by the Euroarea member states in proportion to their share in the paid-up capital of the ECB. The $€ 440$ billion lending capacity of the EFSF was combined with loans up to $€ 60$ billion from the European 
adequate bank capital and retaining government debt sustainability.

Spain experienced a very similar situation with Ireland when the housing prices collapsed thus affecting the stability of its banking sector. The country was not able to bail out the problem banking institutions based on its own resources and, therefore, on 25 June 2012, it submitted an official request to the Eurogroup to receive a loan facility of up to $€ 100$ billion. The assistance was provided some months later by the European Stability Mechanism (ESM), which came into effect on 27 September 2012 replacing the EFSF fund (Eurogroup, 2013). A first disbursement of $€ 39.47$ billion took place in December 2012, and a second disbursement of $€ 1.86$ billion occurred in February 2013. The total funds of $€ 41.33$ were disbursed in the form of ESM bills and floating rate notes with maturities ranging from 10 months to 3 years. In return, the Troika determined a set of bank-specific measures, which were deemed to be necessary for the soundness of the Spanish banking system to be restored. Besides the bank-specific measures, a number of structural reforms were also identified to help improve public finances and strengthen the Spanish economy as a whole.

Portugal also slipped into the crisis in the first half of 2011, when it found itself unable to repay or refinance its government debt and support the stability of its banking industry. At that time, the Portuguese bond spreads had risen to unsustainable levels prompting the government to apply for a funding programme to the Eurogroup. Indeed, in May 2011, Portugal has drawn a cumulated $€ 78$ billion from the Troika. In order to accomplish the rescue programme, a number of austerity measures had to be successfully applied: public servant wage cuts, value added tax rise, higher income taxes, pension cuts, recapitalisation of the banking sector, and privatisation of public companies were some of the reforms which had to be made in the context of the loan facility agreement between Portugal and the Troika.

Another periphery country of the Euro-area, which was seriously hit by the crisis was Greece. In contrast to Ireland and Spain, Greece had a relatively healthy banking system which was neither highly exposed to derivatives and structured financial products, nor to residential mortgages. Rather, the debt crisis in Greece was a combination of considerable structural weaknesses of the national economy along with a decade of overly high deficits and debt-to-GDP levels on public accounts. Moreover, the competitiveness of the Greek economy against that of the core Eurozone member states had fallen for years thereby building up considerable

Financial Stabilisation Mechanism (EFSM) reliant on funds raised by the European Commission using the EU budget as collateral and up to $€ 250$ billion from the IMF to obtain a financial safety net up to $€ 750$ billion. 
macroeconomic imbalances.

In April 2010, the recorded sharp increase in the Greek bond yields pushed public debt levels to the limits of sustainability. The private capital markets were practically no longer available for Greece as a funding source and, hence, the Greek government asked the financial support of the Troika. On 2 May 2010, the Troika responded by launching a $€ 110$ billion bailout loan to rescue Greece from sovereign default. The loan was conditional on the implementation of a set of austerity measures and structural reforms similar to those imposed to Portugal. A year later, the deepening of the recession in Europe along with a delayed implementation of the agreed reforms by the Greek government, revealed the need for Greece to receive a second bailout package of $€ 130$ billion, which also included a bank recapitalisation package of $€ 48$ billion. Notwithstanding the additional loan facility, the debt remained at non-viable levels and, hence, the Greek Government in coordination with the Troika decided that debt had to be restructured. All private creditors holding Greek government bonds were required to sign a deal accepting extended maturities, lower interest rates, and a 53.5\% face value loss.

The haircut in the Greek debt pushed several European banks close to insolvency because the capital buffers of those banks were not enough to absorb the impending losses. The pressures were intensified by the banks' own defensive measures, such as asset sales, which contributed to the downturn in asset prices and caused further losses in the banks' trading books. The most devastating effect of the Greek debt haircut was on the banking system of Cyprus. Cypriot banks which had been already weakened due to the deep recession in which the Cypriot economy entered in 2009, were highly exposed to Greek government bonds and, hence, they had to suffer great losses due to the haircut. Citing difficulties in supporting its banking sector from the exposure to the Greek debt, the Cypriot Government requested an emergency loan from the Troika on 25 June 2012. On 16 March 2013, the Troika agreed on a $€ 10$ billion deal with Cyprus, making it the fifth country -after Greece, Ireland, Portugal and Spain- to receive money from the EU and the IMF. As part of the deal, a one-off bank deposit levy of $6.7 \%$ for deposits up to $€ 100,000$ and $9.9 \%$ for deposits in excess of $€ 100,000$ was announced on all domestic bank accounts. Measures were put in place to prevent withdrawal or transfer of moneys representing the prescribed levy. Like it happened with all other bailed-out economies, a set of austerity measures included cuts in civil service salaries, social benefits, allowances and pensions, tax increases, and others were also agreed to by implemented by the Cypriot government in return to the rescue package received from the Troika. 


\subsection{The response of the ECB to the twin crisis}

Motivated by the fact that banking institutions in the Eurozone were facing substantial solvency problems, financial markets were jittery, and sovereigns were not able to effectively support their banking systems without deteriorating their public finances, ECB introduced a set of unconventional policy measures to support European banks. In particular, in May 2010, the ECB launched the Securities Markets Programme (SMP) to address tensions in certain market segments that hampered the monetary policy transmission mechanism. The SMP referred to the process with which the ECB aimed to influence prices in the Euro-area as a whole via its interest rates. Under the SMP, should this mechanism be disrupted by dysfunctional market segments and the ECB's rate signal not be transmitted evenly to all parts of the Euro-area, the ECB could intervene by buying, on the secondary market (i.e. from banking institutions and against market prices), the securities that it normally accepts as collateral. The last SMP purchases took place in February 2012 and the Programme came to an end in September 2012.

Having announced in August 2012 the possibility of Outright Monetary Transactions (OMTs) in secondary sovereign bond markets to safeguard an appropriate monetary policy transmission and the singleness of the monetary policy, the ECB went on to announce the technical features of the OMTs in September 2012. The objectives of the OMTs were to safeguard an appropriate monetary policy transmission mechanism and to preserve the singleness of the monetary policy across the Euro-area by providing a fully effective backstop to avoid destructive scenarios with potentially severe challenges for price stability in the Euro-area. In contrast to the SMP, a necessary condition for the OMTs was strict and effective conditionality attached to an appropriate EFSF/ESM programme in order to preserve the primacy of the ECB's price stability mandate and to ensure that governments retain the right incentive to implement required fiscal adjustments and structural reforms. A further difference to the SMP was that OMTs were ex ante unlimited and would take place in secondary government bond markets with maturities of one to three years. Finally, the ECB would accept the same (pari passu) treatment as private or other creditors for all of its OMT holdings. As it was the case with the SMP, the creation of liquidity through OMTs was fully sterilised, implying that the total additional liquidity injected through OMTs up to a certain week was absorbed from the market a week later. The sterilisation of liquidity was, for example, executed through an offer of fixed-term deposits that banking firms could make in the central bank. The net effect of purchases and sterilisation on the overall liquidity in the interbank market was thus neutral.

ECB further introduced the so-called Long Term Refinancing Operation 
(LTRO), which was a cheap loan-grating scheme for European banks. The first round of LTRO was carried out by ECB on 21 December 2011. Through that unconventional intervention, the monetary authority of the Euro-area provided approximately $€ 1$ trillion of cheap loans to the European banking companies. The loans were due to be repaid within 36 months at a rate of $1 \%$. In total, 523 banks, primarily those headquartered and located in the weak Eurozone periphery, participated in the first round of LTRO borrowing the total amount of $€ 489.2$ billion. On 28 February 2012, a second LTRO round of $€ 529.5$ billion was launched to which 800 banks participated.

\section{The rationale and the reasoning behind the establishment of the EBU}

On the one hand, the late 2000 s crisis highlighted some of the weaknesses in the legal and institutional framework of the European Monetary Union (EMU). On the other, it revealed the inherent inadequacies in the fragmented nature and structure of the European banking markets, which were largely reflected in the lack of an established set of bank supervision and resolution principles and strategies. Indeed, the implementation of the EMU with the induction of the common currency in 1999 significantly reinforced the level of integration in the financial and banking markets across the Eurozone economies. A massive growth in cross-border banking transactions was observed from the early 2000s to the beginning of the crisis in late 2007. Such a growth highly contributed to the strengthening of the ties among national banking systems across the Euro-area ${ }^{4}$.

However, there is also a flip side of the coin. National authorities had fewer tools at their disposal to safeguard the maintenance of financial stability after the induction of the single currency. Importantly, the function of the 'lender of last resort' -performed by the central banks of the sovereigns prior to the formation of the Euro-area- could no longer be performed effectively at either the national level or at the European level as the crisis revealed. In fact, the legal and institutional absence of the 'lender of last resort' function gave birth to greater potential for financial instability, especially in the context of the substantial growth in cross-border banking transactions which had led to a dramatic increase in the degree of interrelationship amongst banking firms in the Eurozone, the rapid expansion of bank balance sheets, and the exposure of banks to residential mortgage lending and to a set of highly sophisticated and complicated modern activities like securitisation and derivatives trading.

4. For a thorough analysis of the cross-border banking activity in Europe, the interested reader can refer to Allen et al. (2011). 
The strong ties between the sovereigns of the Euro-area periphery and their banks were not relaxed after the intervention of the Troika in the sense that the provided financial aid was not injected directly to the banks, but added to the public debt of the bailed out economies thus worsening the level of their public finances. This sovereign debt-bank doom loop further undermined the ability of the Eurozoneperiphery member states to rescue or resolve the troubled banking organisations. It is important to mention at this point that the crisis did not only hit the countries with outright banking crises and sovereign debt crises. Rather, it spread all over Europe also affecting some of the core Euro-economies like France and Germany, which seemed to be relatively more stable.

The ECB's SMPs in 2010 and 2011, the LTROs in 2011 and 2012, and the announcement of OMTs in 2012 (as earlier presented) all played a supportive and stabilising role for the financial systems and the economies in Europe. Notwithstanding the actions taken by the ECB to address the emerging problems, the Eurozone still experiences negative or very low growth, suffers from high indebtedness of private households, firms, and sovereigns, and has to deal with several undercapitalised or weak banking sectors. This shows that the actions of one of the most powerful EU institutions, the ECB, may not be enough to address the problems caused by a severe financial crisis, especially when these actions are not accompanied by a set of harmonised rules and policies at the EU-level ready to be implemented in case of emergency.

To continue, banking legislation in Europe leaves room for significant divergences in national rules. This has created a regulatory patchwork, leading to legal uncertainty, enabling banks and other financial institutions to exploit any regulatory and supervisory loopholes. The crisis has shown that, in an environment of interrelated economic and financial systems like that of the Eurozone, these divergences can have very disruptive effects. It is, therefore, crucial to use the same definition of supervisory and regulatory aggregates and the same methodologies for the calculation of the respective rules across the banking sectors of the Euro area. Moreover, once risks generated under the curtain of minimum harmonisation materialise, the impact is not contained within national boundaries but spread across the economies affecting them in a disproportionate manner. The crisis highlighted the need for swift and decisive action at the EU-level in order to avoid situations in which bank resolution is conducted at the national level. This is expected to curb uncertainty and prevent contagion of other parts of the Euro-area.

The Euro-area member states were reluctant to transfer prudential supervision and bank resolution functions from the national to the supranational level prior to the crisis. Indeed, home country control of supervision dominated and financial sup- 
port for failing banks came at a large degree from national fiscal authorities according to national priorities during the twin crisis. The crisis revealed the urgent need for European countries to overcome their entrenched opposition in several important areas. The collapse or threatened collapse of a range of cross-border European banks in the context of the twin crisis as described above and threats to other banking systems reinforced the rationale of moving beyond unilateral or ad hoc arrangements. The time seemed to have come for a common union among the banking sectors of the Euro-area economies to be created (see European Commission, 2013).

\section{The establishment of the EBU}

The European Council on 29 June 2012 affirmed that “...it is imperative to break the vicious circle between banks and sovereigns which has led to over $€ 4.5$ trillion of taxpayers money being used to rescue banks in the EU" and proceeded to propose 'A Roadmap towards a Banking Union'(European Commission, 2012). The EC's proposals were based on the vision of the Presidents of the European Council (then Herman Van Rompuy), the Eurogroup (then Jean-Claude Juncker), the European Commission (then José Manuel Barroso) and the ECB (Mario Draghi) to establish a more stable, coherent, and prosperous architecture for the EMU by launching the following four unions over the next decade (Van Rompuy, 2012a and 2012b) ${ }^{5}$ :

a) a banking union, comprising an integrated financial framework,

b) a fiscal union, comprising an integrated budgetary framework that will go beyond the fiscal compact,

c) an economic union, comprising an integrated economic policy framework to ensure growth, employment and competitiveness, and

d) a political union, enhancing the democratic legitimacy and accountability of all the decision-making bodies within the EU.

The European Councils on 29 June 2012 and on 14 December 2012 were those that took the decision to establish the EBU. The main aims of the EBU are to:

a) restore confidence in the European banking systems,

b) strengthen the resilience of European banks,

c) break the sovereign debt-bank doom loop that (mostly) plagued the eurozone periphery,

d) counteract the growing fragmentation of European banking and financial markets,

5. Schmidt and Weigert (2012) examine the establishment of the EBU as an indispensable part of the future EU governance structure. 
e) play a complementary role to the operation of EMU, protecting the euro from future shocks.

At its current form, the EBU is based upon two key pillars: a Single Supervisory Mechanism (SSM) and a Single Resolution Mechanism (SRM) ${ }^{6}$. Along with these pillars (which we will describe and explore below), the EBU is designed to rely on a set of rules, the so-called Single Rulebook (coined as a term by the European Council of June 2009), which is applicable to all the 28 EU member states and refers to a corpus of legislative texts covering the operation of all financial actors and products in Europe. Banking institutions across the Single Market will have to comply with these common rules. Such a harmonisation is expected to guarantee -to a significant extent- a common level playing field for banks and create a real single market for financial services and products. In addition, the Single Rulebook will ensure the uniform application of Basel III in all EU member states, thus filling the existing regulatory loopholes and contributing to a more effective operation of the Single Market.

The first pillar of the EBU, the SSM, came into force in November 2014 with the objective to ensure that a set of common supervisory standards are applied in a consistent manner across the Eurozone banking industries (ECOFIN, 2013b). According to its mandate, the SSM supervises the banking sectors of the Euro-area, as well as those of any non-Euro-area member state wishing to join in the future. The SSM has been entrusted with an extensive set of micro- and macro-prudential powers, covering all the key tasks related to the prudential supervision of banking institutions. The SSM possesses early intervention powers that allow action with respect to banks which are approaching the point of insolvency. These intervention powers are in accordance with the Bank Recovery and Resolution Directive (BRRD), which provides national authorities with a common set of tools for dealing with failing banks, and requires banks to facilitate this process by providing information for recovery and resolution planning purposes to the authorities as well as meeting the specified resolvability requirements?

In terms of the SSM governance structure, the ECB is the central authority of the SSM and is supported by the supervisory authorities of the Eurozone member states. It is entrusted with the whole toolbox for banking supervision including: authorising and withdrawing bank licences, collecting on- and off-site information,

6. Pisani-Ferry et al. (2012) provides a set of suggestions and comments on the structure and design of the EBU.

7. In June 2014, the BRRD was finalised and published in the Official Journal of the EU, creating a harmonised framework across Europe for dealing with the problem of the 'Too big to fail' banks through bank recovery and resolution. The BRRD came into effect at the end of 2014. 
undertaking on-site inspections in cooperation with national supervisors, and validating banks internal models and risk controls. Whenever necessary, the ECB is also able to solicit additional capital, liquidity and other prudential requirements. The governance structure of the SSM has been designed to separate the ECB's monetary policy from its supervisory role, the latter entrusted to the Supervisory Board. While the decisions are formally adopted by the Governing Council of the ECB, the Supervisory Board is, de facto, the main decision-making body for supervisory matters. The ECB Governing Council cannot alter the decisions of the Supervisory Board, but only prevent their entry into force. Such a veto power is to be exercised when the decision is seen to be in conflict with the monetary policy objectives. Further, the SSM has its own accountability framework vis-à-vis the European Parliament, the Eurogroup and the national parliaments. Accountability applies to the Chair of the SSM's Supervisory Board, and not to the ECB's President. This is intended to avoid any confusion among the two sets of tasks and also protects the ECB's independence.

At present, the ECB directly supervises 130 banks which are considered to be 'significant' according to the criteria laid down in the SSM Regulation (European Council, 2013). These criteria refer to banks which: a) have a total value of assets of more than $€ 30$ billion, b) represent more than $20 \%$ of domestic GDP (unless less than $€ 5$ billion in assets), and c) receive direct assistance from the EFSF/ESM. Also, the criteria concern the three most systemically important banks in each member state. The 130 supervised banking firms are less than 5\% of all active Euro-area banks; however, they cover around $85 \%$ of the total banking assets. The rest of the banks are supervised by national authorities and have to comply with the ECB regulations, guidelines, and instructions. In any case, the ECB keeps access to the relevant data of all the existing banks in the Eurozone and can, at any time, decide to exercise direct supervision of any other bank if necessary. Overall, the SSM is expected to remove home bias from the task of banking supervision.

As highlighted by the European Councils in December 2012 and June 2013, it is not effective to have a single mechanism for bank supervision at the EU-level and, at the same time, to leave the resolution of banks to national authorities for two main reasons: on the one hand, it is very likely for the ECB and national authorities not to share the same views on how to deal with ailing banks, which can lead to delays and problems in the bank resolution process. On the other, without a common resolution mechanism, the expectations of investors and market participants about the ability of the sovereigns to deal with problem banks can turn to be very low, thus reinforcing negative feedback loops between the sovereigns and banks, and, further, maintaining the fragmentation across the Single Market (ECOFIN, 2013a). 
Hence, on 10 July 2013, the EC proposed the creation of the SRM. The SRM, which is scheduled to come into force in the beginning of 2015, will be applied to all those banks covered by the SSM. It is considered to be a necessary complement to the common supervisory framework of banks as it brings liability and control into alignment. Its key objective is the uniform implementation of the set of common resolution rules and procedures in all European sovereigns. The SRM is expected to remove the existing distortions of the market structure of national banking industries, which are inter alia caused by discrepancies in the national resolution strategies and practices, and the lack of a unified decision-making process at the EU-level. Moreover, it aims at aligning the level of responsibility for supervision and resolution. This will significantly reduce the risk of uncoordinated actions at different levels in the case a bank gets in trouble, which, in turn, will benefit the Single Market by forming a common level playing field for all the European banking organisations ${ }^{8}$.

The SRM fully respects member states' budgetary sovereignty: under no circumstances will the SRM be able to require member states to finance resolution from their own budgets. In addition, the SRM is planned to only intervene when private sector solutions are not successful in dealing with a bank failure. This implies that institutional protection schemes and other intra-group financing support mechanisms set up by many financial holding groups and companies across Europe will maintain their current role.

One of the key elements of the new resolution framework under the SRM is that financial aid can -in principle- be granted by national authorities only after shareholders and creditors have assumed resolution costs. In other words, under this 'bail-in' regime, investors will be the first in line to shoulder the costs of a bankruptcy under the rationale that they are the ones who assume the risks and benefit from returns in the first place. As a consequence, the burden of a bank failure is shifted away from the public. To ensure the availability of funds so that a problem bank can continue its operation while it is being restructured, each national bank is asked to contribute to the respective National Resolution Fund (NRF) set up by the BRRD. Contributions are charged in proportion to banks' liabilities, but no contributions will be charged on own funds and deposits covered by guarantee schemes 9 . This implies that the larger the bank, the higher its contribution to the relevant NRF.

8. Howarth and Quaglia (2014) provide a comprehensive analysis of the construction of the SRM and the various aspects of its operation.

9. Deposits up to $€ 100,000$ are protected by the deposit guarantee scheme set at the EUlevel following the harmonisation of the national deposit guarantee policies and are never bailed in; these are called 'covered deposits'. 
Contributions are further adjusted in accordance with the risk-taking behaviour of each individual banking institution. To this, a number of risk indicators against which the risk profile of each institution are assessed. In this context, the principle of proportionality based on a special lump-sum regime for small banks is applied. This reflects the fact that, in most cases, small institutions have a lower risk profile and are less likely to use resolution funds. Banks (in the Euro-area) representing $1 \%$ of the total assets will pay $0.3 \%$ of the total contributions. The overall target level of each NRF is of at least $1 \%$ of the amount of the total covered deposits of all the banking institutions authorised in its territory by 31.12.2024 (European Commission, 2014). This target level of bank contributions is considered to be sufficient to finance the resolution process in case of financial turmoil.

A Single Resolution Fund (SRF), which refers to a unified system of contributions at the EU-level is further set up by the BRRD. The SRF will be built up by bank contributions over an eight-year transition period during which it will be composed of its national counterparts. In the context of the EBU, the NRFs of the 28 member states will be pooled together and gradually replaced by the SRF. As it is the case for NRFs, the SRF will be financed by ex ante contributions of banking organisations thus protecting taxpayers' money. Contributions to the SRF will be also calculated in a way that will reflect the size of banks and the risks inherent in the operation of different types of banks (commercial banks, savings banks, cooperative banks, and others) and their business models. The SRF will have a target level of at least $1 \%$ of the amount of covered deposits of all the institutions in the Eurozone (European Commission, 2014).

\section{Some final reflections}

During the late 2000s crisis, which escalated to an exploding mixture of financial and sovereign crunches in Europe, a significant part of the European banking system has been kept afloat by public capital injections and state guarantees, as well as the support of the ECB. The key lesson we have learnt so far is that economic dislocations without the proper legal and institutional arrangements to tackle with troubled banking institutions have devastating effects on the financial system, the real economy, the taxpayers and the whole society. And regaining growth proves to be a painful, tedious and long-lasting process.

The establishment of the EBU creates a comprehensive legal and institutional framework necessary to mitigate the negative effects of future economic and financial shocks on the operation of banks and, at the same time, lifts the burden of bank rescues from sovereigns and taxpayers by forcing losses primarily on bank shareholders and creditors but also to uninsured depositors. Moreover, the EBU is 
expected to eliminate any serious flaws in the institutional make-up of the EMU ${ }^{10}$. For the ECB, an integrated banking space will ease the transmission of monetary policy and increase the effectiveness of monetary policy. A successful European banking union will also relieve the ECB of several of the tasks and unconventional measures undertaken during the crisis (European Council, 2013).

The EU has come a long way since the beginning of the crisis. Major steps have been taken already, but there is still some work ahead. The banking union is not an end by itself. Further determination is needed in completing the constitutional framework envisaged under the four unions, the four cogwheels that must work together in a harmonised manner and towards the same direction. Completing the implementation of the banking union will take a great deal of additional hard work and cooperation ${ }^{11}$. However, once it is in place, Europe will be proud of having a healthier banking system, which will be more resilient to future shocks.

Acknowledgements: The study has been benefited from discussions with participants in the Financial Intermediation Network of European Studies (FINEST) winter workshop which was held in Rome on 10 December 2014 and hosted by the Italian Banking Association. The theme of the workshop was "Banking Union: Arrival or Starting Point?".

\section{References}

Allen, F., T. Beck, E. Carletti, E. Philip, R. Lane, D. Schoenmaker, and W. Wagner, 2011. Cross-border banking in Europe: Implications for financial stability and macroeconomic policies. CEPR, London.

Begg, I., 2012. Banking Union: Inevitable, but profoundly challenging?. CESifo Forum 13 (4), pp. 15-20.

Breuss, F., 2013. Towards a new EMU. WIFO Working Paper 447.

ECOFIN, 2013a. Council agrees position on bank resolution. Brussels, 27 June 2013.

ECOFIN, 2013b. Council approves single supervisory mechanism for banking. Brussels, 15 October 2013.

Eurogroup, 2013. ESM direct bank recapitalisation instrument: Main features of the operational framework and way forward. Luxembourg, 20 June 2013.

European Commission, 2012. A Roadmap towards a Banking Union, COM (2012) 510 final. Brussels, 12 September 2012.

European Commission, 2013. A comprehensive EU response to the financial crisis: substantial progress towards a strong financial framework for Europe and a banking union for

10. For details on the new architecture of the EMU, see Breuss (2013).

11. Insightful discussions of the challenges ahead are offered by Begg (2012) and Micossi (2012). 
the Eurozone. Memo, Brussels, 17 December 2013.

European Commission, 2014. Commission adopts detailed rules on contributions of banks to resolution funds. Strasbourg, 21 October 2014.

European Council, 2013. Specific tasks on the European Central Bank concerning policies relating to the prudential supervision of credit institutions. Council Regulation $1024 / 2013$.

Howarth, D., L. Quaglia, 2014. The steep road to European Banking Union: Constructing the Single Resolution Mechanism. Journal of Common Market Studies 52 (4), pp. 125-140.

Koetter, M., Wedow, M., 2010. Finance and growth in a bank-based economy: Is it quantity or quality that matters? Journal of International Money and Finance 29 (8), pp. 15291545.

Micossi, S., 2012. Banking Union in the making. CESifo Forum 13 (4), pp. 21-25.

Pisani-Ferry, J., A. Sapir, N. Véron, and G.B. Wolff, 2012. What kind of European Banking Union?. Bruegel Policy Contribution 2012/12, Bruegel, Brussels.

Schmidt, C.M., B. Weigert, 2012. A Banking Union for Europe: Part of an encompassing long-term governance structure, no short-term fix. CESifo Forum 13 (4), pp. 3-9.

Van Rompuy, H., 2012a. Towards a Genuine Economic and Monetary Union, Report by President of the European Council Herman Van Rompuy. Brussels, 26 June 2012.

Van Rompuy, H., 2012b. Towards a Genuine Economic and Monetary Union, Report by President of the European Council Herman Van Rompuy. Brussels, 5 December 2012. 
